\title{
REHABILITATION OF THE HANDICAPPED CHILD - WHO CARES FOR THE CAREGIVER?
}

\section{- Seyi L Amosun BSc Physiotherapy, PhD Physiology, Physiotherapy Department, University of the Western Cape}

\section{Benson A Ikuesan MSc Clinical Psychology}

\section{- Iyabo J Oloyede BSc Physiotherapy}

\section{INTRODUCTION}

Rehabilitation has been defined as the restoration of the disabled to their fullest physical, mental and social capability $^{1}$. In caring for the disabled, a "team" approach to the disabled's problems is highly recommended. This is a process in which many people have various roles to play in the care of the disabled, with the professional contribution seen as one among many. The disabled and the caregiver are included in the team, and they have significant roles to play. In a situation where the disabled is a child, the caregiver assumes a greater role.

Caregivers of chronically disabled patients are often exposed to many burdens and disappointments that may limit their quality of life. Parents of chronically ill children were reported to experience more marital stress than parents of healthy children ${ }^{2}$. Such parents were also prone to

\section{ABSTRACT \\ The mental health of caregivers of handicapped children ( $n=68)$, and of caregivers of children with minor ailments $(n=40)$, was assessed using the General Health Questionnaire (GHQ). In the cross-sec- tional study, the caregivers of handicapped children had a signifi- cantly higher mean score which was above the threshold score. This suggests that the task of caring for disabled children may have a stressful impact on the caregivers which may contribute to psychiatric morbidity. There is need to periodically assess the mental health of the caregiver, even as the rehabilitation of the handicapped child progresses. Addressing the psychological disturbances in the caregiver should form part of the treatment of the handicapped child.}

\section{OPSOMMING}

Die geestesgesondheid van versorgers van gestremde kinders $(n=$ 68 ), en van versorgers van kinders met minder ernstige siektes $(n=$ 40), is bepaal deur middel van die Algemene Gesondheidsvraelys. In die deursneestudie het die versorgers van gestremde kinders 'n betekenisvolle hoer mediaan-telling gehad, wat hoer as die drempeltelling was. Dit dui aan dat die taak om gestremde kinders te versorg, 'n stresvolle impak op versorgers mag hê, wat tot psigiatriese morbiditeit mag bydra. Daar bestaan dus die behoefte om die geestesgesondheid van die versorger van tyd tot tyd te bepaal, terwyl die rehabilitasie van die gestremde kind vorder. Aandag aan die psigologiese versteuring van die versorger behoort deel uit te maak van die behandeling van die gestremde kind. depression, mood lability, and the tendency to feel tired more than the parents of normal children 3,4 . Johnson and Deitz ${ }^{5}$ confirmed that mothers with physically handicapped children had difficulty getting away from home to participate in social activities. It was assumed that the time-demand placed on a mother caring for the physical needs of a disabled child interfered with the mother's ability to leave home and engage in other activities.

In a longitudinal study on families with Down's syndrome babies $(n=30)$, matched with a control of another set of families with normal babies $(n=30)$, followed up for 18 to 24 months, few differences were reported in the physical or mental health of the parents in the two groups ${ }^{3}$. Though a similar number of parents were treated for psychiatric problems in the two groups, there were more mothers with Down's syndrome babies exhibiting clinically recognisable depression.

Another longitudinal study in Britain ${ }^{6}$ made use of a modified form of the General Health Questionnaire (GHQ) to assess the mental health of carers of stroke patients. Significant depression was seen in $11-13 \%$ of the carers ( $n$ $=302$ ) over the first two years after the onset of the stroke. In the first six months after the stroke, increased anxiety was the most commonly reported symptom in the carers. The patients' functional disability was associated with depression in the carers over the first year after the onset of stroke. However, the level of anxiety and emotional distress observed in the carers after two years of the onset of stroke, was unrelated to the physical disabilities in the patients. The hypothesis presented from the findings suggested that the depression in the carers was related to the occurrence of a major, life-threatening illness, and not because of the physical stress of caring.

Romans-Clarkson et $\mathrm{al}^{4}$ also reported the findings of a cross-sectional study in which the mental health of parents of physically and mentally handicapped pre-school children was compared with that of parents of healthy preschool children. The degree of morbidity as ascertained by the GHQ, was significantly greater in the mothers of handicapped children $(n=54)$ than in the mothers of children in the control group $(n=184)$. Thirty-five per cent of subject mothers scored above the usual threshold score, while $21 \%$ of the control mothers had a similar score. The scores for the fathers in the subject group $(n=43)$ did not differ significantly from those of the control group $(n=132)$. Twenty-one per cent of subject fathers and $16 \%$ of control fathers scored above the threshold scores.

Some of the stress outcomes reported in a group of caregivers from two urban communities in the United States of America were heart attacks, stroke, alcoholism, increased smoking and depression/anxiety ${ }^{7}$. Minkler et al ${ }^{8}$ reported some other adverse health consequences, including insomnia, back and stomach pain, and exacerbations of 
previously controlled chronic conditions such as hypertension and arthritis, among middle-aged and older women caregivers seen at some public hospital clinics. We believe that these detrimental effects on the health of the caregivers of handicapped children may jeopardise the efforts at rehabilitation of these children. The role of physiotherapy and exercises as a potential technique to prevent stress-related disturbances has been reported ${ }^{9}$.

We have observed that caregivers, who brought disabled children to the Department of Physiotherapy, University College Hospital, Ibadan, Nigeria, for treatment, often expressed anxieties about their wards. On many occasions, the caregivers were observed to be discouraged with the prognosis of their wards. There were unconfirmed reports that some of the caregivers made attempts to "do away" with their handicapped children. Most of these caregivers were the parents of the handicapped children, but there were instances in which other relatives (grandparents, aunts, sisters) fulfilled the roles of caregivers.

Our study was therefore aimed at assessing the impact of caring for handicapped children on the mental health of the caregivers. Earlier studies have compared the mental health of caregivers of handicapped children with that of caregivers of non-handicapped children who had no reported reason to take their children to the hospital ${ }^{2-4}$. From our personal observations, we noted that there was a general fear among people coming to the hospital, as well as anxiety over the state of the patient brought to the hospital. It is not impossible that this state of fear and anxiety could be a major contributory factor to the mental stress on the caregivers. However, the caregivers of non-handicapped and healthy children may have no visible cause for such anxiety. This study, therefore, focused on caregivers of non-handicapped children who were brought to the hospital because of minor medical ailments, for comparison. This is to eliminate the possible psychological impact of taking a child to the hospital.

This study was based on the hypothesis that caregivers of handicapped children would have higher scores in the GHQ than caregivers of non-handicapped children. We also expected that the level of emotional distress in the carers of handicapped children would be related to the duration of time for which the carers cared for the handicapped child (defined as the period between the time of diagnosis of the handicap in the child by a doctor and the time of inclusion of the child in this study). The outcome of this study may provide support for the suggestion that in the management of the handicapped child, an assessment of the caregiver should be carried out at various stages to provide intensive support for the carers where and when necessary.

\section{METHOD}

This study was conducted in Ibadan, Nigeria. Ibadan, the capital of Oyo State of Nigeria, is one of the largest cities in Africa. It is located about $150 \mathrm{kms}$ from Lagos, the former capital of Nigeria. Within the city, health services are provided by government and private institutions. However, our preliminary study revealed that handicapped children are often referred to government hospitals for rehabilitation (unpublished data). This observation guided us in selecting the two main government hospitals in the city. These were Oni Memorial Hospital, a hospital mainly for children (controlled by the Oyo State Government), and the University College Hospital (UCH), a Federal Government institution. The areas of $\mathrm{UCH}$ covered throughout the study were the physiotherapy department and the children's outpatient department. At Oni Memorial Hospital, the physiotherapy department was covered.

\section{SUBJECTS}

Two groups of subjects were involved in this study. Group 1 consisted of caregivers of handicapped children receiving physiotherapy treatment at either the University College Hospital or at Oni Memorial Hospital. The criteria for selecting a handicapped child were similar to those of Johnson and Deitz $z^{5}$. A handicapped child was defined as having difficulties in one or more specified areas of function, namely ambulation, feeding, toileting and communication. Sixty-eight handicapped children, aged 3-60 months (mean 19.5, SD 6.9) were identified. This sample included children with cerebral palsy $(n=36)$, poliomyelitis $(n=26)$, and paraparesis $(n=6)$.

Group 2, which was the control group, consisted of caregivers who brought 40 ill children, aged $6=72$ months (mean 18.0, SD 7.3), to the children's outpatient department of the University College Hospital. The diagnoses included cases of cough $(n=10)$, malaria $(n=24)$, measles $(n=2)$ and skin rashes $(n=4)$. For both groups, a caregiver was identified as the individual primarily responsible for meeting the daily physical needs of the child, particularly since the onset of handicap or illness, which included bringing the child to the hospital for treatment. The caregivers in Group 2 were within the same age range as those in Group 1.

\section{INSTRUMENTATION}

A standard questionnaire ${ }^{10}$, the General Health Questionnaire $(\mathrm{GHQ})$ was used to elicit information from the caregivers. GHQ is a self-rated screening tool designed to detect non-psychotic emotional illness in an individual. The 28-item questionnaire consists of four sub-scales (A to D), detecting somatic symptoms (A), anxiety and insomnia (B), social dysfunction (C) and severe depression (D). The questionnaire was translated into the local language for those who could not read English.

Each of the 28 items of the questionnaire has four responses. Responses one and two were considered insignificant to affect the health status of an individual. The scoring method used was 0-0-1-1 rather than the Likert rating scale $^{10}$. Therefore, the severity rating, or the sum of all the morbid ratings, was carried out by counting the number of times the caregiver responded to each item by responses three and four. The maximum obtainable score was 28 , with a score higher than four (the threshold score) suggesting that the individual may receive a psychiatric diagnosis if examined. 


\section{PROCEDURE}

Individuals who brought the children to the hospitals for physiotherapy or for medical treatment, were interviewed to establish their relationship with the children. Those identified as the caregivers were then approached for consent for inclusion into either the experimental or the control groups. The questionnaire was administered to the caregivers between $08 \mathrm{~h} 00$ and $12 \mathrm{~h} 00$ on various days of the week, excluding weekends. In addition, demographic data were collected on the caregivers and the children.

\section{DATA ANALYSIS}

In each group, the data collected were subjected to both descriptive and inferential statistical analysis. The results were presented as percentages, means and standard deviations. The unpaired student $t$-test was used to compare the mean scores of the two groups. A correlation analysis of the level of emotional distress and the time duration when the carers cared for the handicapped children was carried out. The level of significance was set at $p<0.05$.

\section{RESULTS}

Table I shows the demographic data of the caregivers in Group $1(n=68)$ and Group $2(n=40)$. The caregivers in both groups were aged 19-50 years, with a mean age of 28.5 years $(\mathrm{SD}=9.1)$ in Group 1 , and a mean age of 29.2 years $(\mathrm{SD}=5.1)$ in Group 2. In each group there were more female caregivers and they were the mothers of the patients. The male caregivers were the fathers. While most of the caregivers were married, 16 caregivers in Group 1 and two in Group 2 were single parents. The male single parents were either separated from their spouses or the spouses were dead. The female single parents were separated from their spouses.

Most of the subjects in both groups were gainfully employed, either with the government or privately. The caregivers in Group 1 had been caring for the children for 2-20 days (the duration of the illness).

Table I: Demographic data and GHQ scores of caregivers

\begin{tabular}{|c|c|c|}
\hline Voriables & Group $1(n=68)$ & Group $2(n=40)$ \\
\hline $\begin{array}{l}\text { Mean Age (years) (SD) } \\
\text { Male caregivers (n }(\%) \\
\text { Female caregivers } n(\%) \\
\text { Married } n(\%) \\
\text { Single parents (male.female:) } \\
\text { Employed } n(\%) \\
\text { Durotion of caring }\end{array}$ & $\begin{array}{l}28.5(9.1) \\
14(20.6) \\
54(79.4) \\
52(76.5) \\
14: 2 \\
58(85.5) \\
3-50 \text { months }\end{array}$ & $\begin{array}{l}29.2(5.1) \\
2(5.0) \\
38(95.0) \\
39(97.5) \\
1: 1 \\
37(92.5) \\
2-20 \text { doys }\end{array}$ \\
\hline \multicolumn{3}{|l|}{ GHQ scores } \\
\hline $\begin{array}{l}\text { Mean (SD) } \\
\text { Range } \\
\text { N(\%) likely to receive psychiatric diag- } \\
\text { nosis if examined }\end{array}$ & $\begin{array}{l}6.8^{*}(5.8) \\
0-23 \\
35(51.5)\end{array}$ & $\begin{array}{l}1.1^{\star}(3.8) \\
0-17 \\
3(7.5)\end{array}$ \\
\hline \multicolumn{3}{|c|}{$\begin{array}{ll}\text { SD } & \text { Standard deviation } \\
\star & \text { Significant difference }(p<0.001) \\
\text { GHQ } & \text { General Health Questionnaire }\end{array}$} \\
\hline
\end{tabular}

The mean scores on the General Health Questionnaire are reported in Table I. Caregivers in Group 1 had higher scores (0-23) than the caregivers in Group 2 (0-17). The difference between the two mean scores was statistically significant $(\mathrm{p}<0.001)$. There was no significant difference between the mean ages of the subjects in the two groups ( $p>0.05)$. More of the caregivers in Group $1(51.5 \%)$ obtained scores above the threshold score of four (range 5-23), while only a few (7.5\%) of the caregivers in Group 2 obtained scores above the threshold score (range 10-17). In Group $1(n=68)$ there was no significant relationship found between the scores obtained and the duration of care $(r=$ 0.0021; $\mathrm{p}<0.05$ ). There was no male caregiver among the caregivers who scored above the threshold score in either group. The items on the GHQ scored most often by the caregivers of handicapped children were: not feeling perfectly well ( $(n=50)$, getting edgy and bad tempered $(n=42)$, feeling constantly under strain $(n=31)$, and inability to enjoy normal daily activities $(n=18)$. Finally, the female caregivers in Group $1(n=54)$ had much higher scores (mean score $=8.49$; range 0.23 ) than the male caregivers ( $n$ $=14$; mean score $=0.71$; range $0-4)$. The difference was statistically significant $(\mathrm{p}<0.001)$.

\section{DISCUSSION}

Daily problems have been identified as one of life's events causing stress in an individual. Caregiving may negatively affect the physical health and economic circumstances of caregivers, and the most consistent consequence may be emotional strain. Most of the caregivers of the handicapped children $(51.5 \%)$ obtained scores above the threshold score, suggesting that these caregivers may receive a psychiatric diagnosis if examined. These caregivers also expressed feelings of ill health, strain, a bad temper and lack of fulfilment. These complaints were similar to those reported in earlier studies ${ }^{3-5,8}$. This pointer to the emotional health status of the caregivers provides an important reminder of the need to consider the physical and emotional needs of caregivers of handicapped children.

It is significant that all the caregivers in Group 1 who could receive a psychiatric diagnosis $(n=35)$ were women. This shows that about $64.8 \%$ of all the female caregivers in Group 1 had scores above the threshold score, while all the male caregivers $(n=14)$ had scores below the threshold score. This may be a pointer to some more serious problems the female caregivers could be facing. Therefore, a delay in identifying the needs of the female caregivers of handicapped children and providing intensive support may lead to additional problems. However, the outcome of this study differs from the report of Romans-Clarkson ${ }^{4}$ in which a smaller percentage of mothers $(35 \% ; n=54)$, and $21 \%$ of the fathers $(n=43)$ of handicapped children had scores above the threshold score. A possible reason why the male caregivers in our study had scores below the threshold score may be related to some cultural attitudes in Nigeria. Often the society holds the woman responsible whenever a child is physically or mentally disabled. Women are therefore the main caregivers with very little support from the men. The male caregivers in this study possibly received some support at home from other female relatives. Thus, the burden of caring for the handicapped child was shared. 
It should be noted, however, that the GHQ scores alone are not conclusive in determining the mental state of the caregivers without a clinical evaluation. In the study of Goldberg and Hillier ${ }^{10}$, in which GHQ scores were related to the clinical status of 200 patients, $116(58 \%)$ had scores above the threshold score, but eight of these were found to be clinically normal. We recommend, therefore, that a clinical psychologist be permitted to interact with caregivers of handicapped children in order to identify such caregivers who may require some form of support.

\section{CONCLUSIONS}

This study has investigated only one aspect of the potential stress on caregivers. It has not measured directly the financial cost, the reduction in the caregiver's social life, the effects on family or marital relationships, or the effects on the physical health of the caregiver. All these factors are also important. However, this study supports the evidence that suggests that caring for a handicapped child is stressful, and may contribute to psychiatric morbidity. Since the caregivers of handicapped children spend a fairly long period of time in our rehabilitation/physiotherapy departments during the treatment of their wards, it is recommended that the mental state of the caregivers be assessed periodically so as to provide supportive therapy where and when necessary.

In addition, clinical studies of the functional health status of caregivers and longitudinal investigations of changes in physical and emotional health are needed. Further research attention should be focused too on the role of formal and informal supports and resources which may help the caregivers of handicapped children cope with their challenging role. Finally, the special needs of these caregivers deserve research attention, and intervention studies.

\section{AEFERENCES}

1. Gloag D. Introduction and a look at some short term orthopaedic rehabilitation. British Medical Journal 1985:290;43-46.

2. Sabbeth B F, Leventhal J M. Marital adjustment to chronic childhood illness: A critique of the literature. Paediatrics 1984:73;762-768.

3. Gath A. The impact of an abnormal child upon the parents. British Journal of Psychiatry 1977:130;405-410.

4. Romans-Clarkson S E, Clarkson J E, Dittmer I D et al. Impact of a handicapped child on mental health of parents. British Medical Journal 1986:293;1395-1397.

5. Johnson C B, Deitz J C. Activity patterns of mothers of handicapped children. Physical and Occupational Therapy in Paediatrics 1985:5;17-25.

6. Wade D T, Legh-smith J, Hewer R L. Effects of living with and looking after survivors of a stroke. British Medical Journal 1986:293;418-420.

7. Burton L M. Black grandparents rearing children of drug-addicted parents: Stressors, outcomes, and social needs. The Gerontologist 1992:32;744-751.

8. Minkler M, Roe K M, Price M. The physical and emotional health of grandmothers raising grandchildren in the crack cocaine epidermic. The Gerontologist 1992:32;752-761.

9. Vingerhoets A J] M, Marcelissen F H G. Stress research: Its present status and issues for future developments. Social Science and Medicine 1988:25;279-291.

10. Goldberg D P, Hillier V F. A scaled version of the General Health Questionnaire. Psychological Medicine 1979:9;139-145.

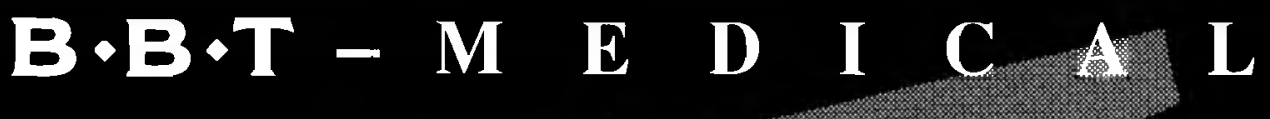

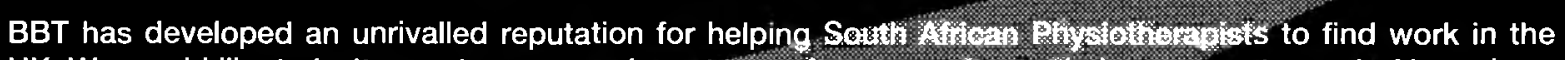

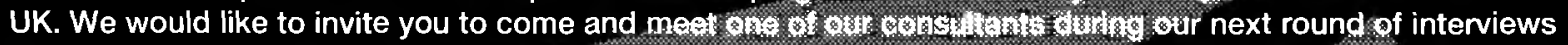

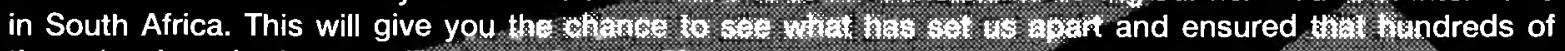

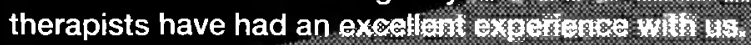

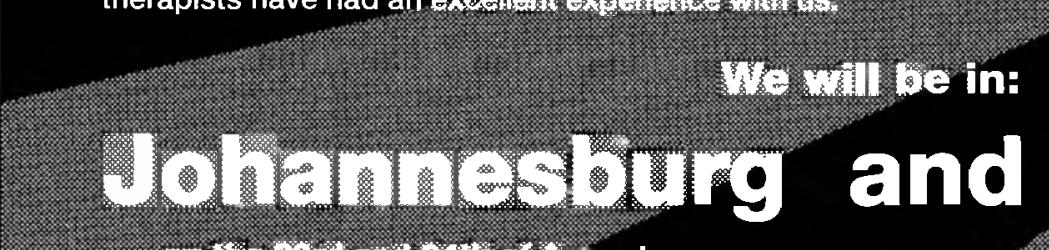

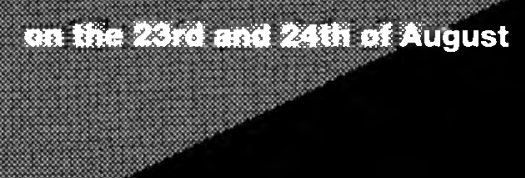

wio zip tates of pay

zrery UK Hospital covered

Excellent bonus schemes

Visa assistance

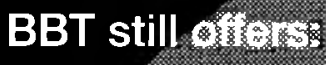

Any length w r s.r:301:06:

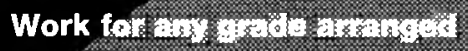

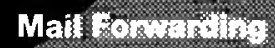

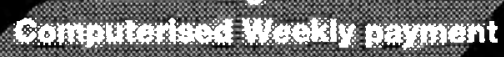

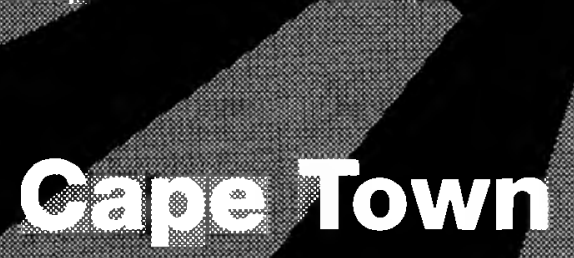

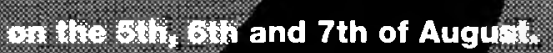

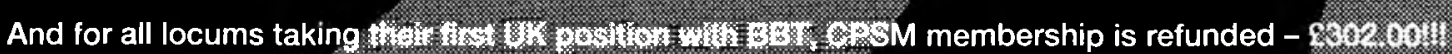

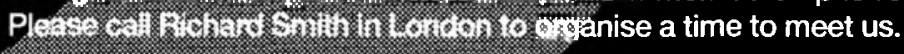

If you are unable to wher:

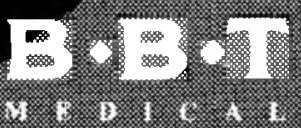

1.

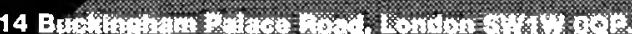

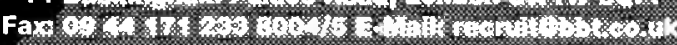

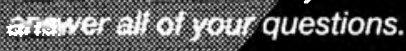

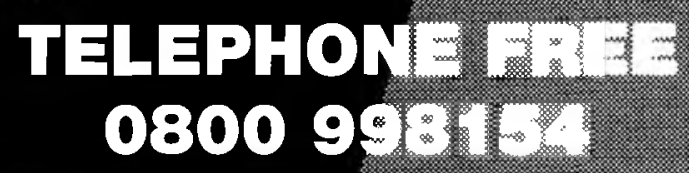

